\title{
Modeling of Corrosion; Steel, Concrete and Environment
}

Raja Rizwan Hussain*

Assistant Professor in CoE-CRT, Civil Engineering Department, College of Engineering at King Saud University, Riyadh, Saudi Arabia

\section{Editorial}

In this editorial, an overview of modeling of corrosion, previous research, related theories and discussions step by step at first for steel, then for steel reinforced concrete and then for steel reinforced concrete under the effect of environment has been presented. In this editorial, material and environmental modeling has been carried out simultaneously for concrete exposed to a variety of environmental actions with varying concrete compositions and dimensions.

By definition corrosion is the chemical or electrochemical reaction between a material, usually metal, and its environment that produces a deterioration of materials and its properties [1]. Due to the phenomenon of passivity, it is not uncommon for the current to change by six orders of magnitude during a corrosion experiment [2]. An electrochemical reaction under kinetic control obeys the Tafel equation [3]. For the range of corrosion phenomena that can be studied with electrochemistry, the ability to measure very low corrosion rates, and the speed with which these measurements can be conducted, an electrochemical corrosion measurement system has become a standard item in the modern corrosion laboratory $[4,5]$. For a simple activation controlled metal dissolution (anodic) process with the rate of the reverse metal ion reduction, reaction is considered to be small and the current density is given by Tafel's Law [3]. It is assumed that the surface concentration of the cathodic reactant did not vary with potential. This is approximately true if the cathodic current density is much less than the limiting mass transfer controlled current density [6]. For a cathodic reaction, neglecting the reverse oxidation reaction, the limiting diffusion current density is given by Fick's 1st Law [7] with a surface concentration of zero.

After reviewing principles which govern modeling of metallic corrosion in general, it is valuable to describe about various states of steel corrosion modeling in concrete, related theories and physical phenomenon. In general, good quality concrete of appropriate mix proportion, compacting, and curing provides an excellent protective environment for steel. The physical protection is afforded by the cover concrete acting as a physical barrier to the access of aggressive species. Chemical protection is provided by concrete's high alkalinity solution within the pore structure of cement paste matrix due to the presence of sodium and potassium oxides in the cement, as well as calcium hydroxide produced in the hydration reactions of cement components $[8,9]$.

Although there are many types of corrosion such as uniform, galvanic, crevice, pitting, environmentally induced, hydrogen damage, intergranular, dealloying, erosion corrosion, only uniform and pitting corrosion relating to reinforcing steel corrosion are discussed here. Uniform corrosion occurs when the corrosive environment is the same to all parts of metal surface. This can be considered as depassivation of protective film of steel due to carbonation which penetration of carbonation front is relatively the same. In contrast, pitting corrosion is localized corrosion which passivity protective film is locally broken down by presence of chloride ion or other halogen ions accelerated at high temperature. Although uniform corrosion consumes a larger amount of steel, localized corrosion is more difficult to predict and monitor and causes rapidly failure because of corrosion concentration at certain points [10-16].

The mechanism of corrosion of steel reinforcement in concrete could be resembled to an electro-chemical cell formation. This phenomena has same ground reaction mechanisms and surrounding environment in principle. Similar to the electrochemical cell, moist concrete acts as an electrolyte, a medium for the movement of charge carriers/ions. Hydroxyl ions move from cathode to anode within the moist concrete and electrons move towards cathode from anode within the steel itself. This causes iron to corrode at the anode site by for formation of various oxides and hydro-oxides. Therefore, corrosion of steel in concrete consists of movement of electrons similar to the movement of electrons in case of electric current flow in the cell. This involves chemical reactions at anode and cathode sites in concrete on the surface of steel bar depending on environment surrounding the steel bar as well as the concrete. Thus the modeling of corrosion in RC structures has to be electrochemical in nature [17-19].

A simple model of electrochemical reactions associated with corrosion deterioration of steel within concrete follows. Oxidization of iron $\left(\mathrm{Fe}^{++}\right)$molecules naturally occurs immediately after the bar is manufactured and exposed to the atmosphere, and will continue so long as sufficient oxygen and moisture are available to react with the steel. Upon exposure to the high $\mathrm{pH}$ environment of concrete, a passive layer of oxidation product forms on the encapsulated steel surface. This passivation process is actually a form of corrosion. However, in the moist, high $\mathrm{pH}$ environment of concrete, the reaction occurs at an ever-decreasing rate. In the absence of aggressive ions, oxidation nearly ceases after a sufficient passive layer has formed. The passive layer normally protects the reinforcement from spontaneous corrosion in a moist, oxygen-rich environment such as concrete. However, chloride ions $\left(\mathrm{Cl}^{-}\right)$that diffuse to the steel surface can disrupt the passive layer and induce corrosion. Generally, metal atoms pass into solution as positively charged ions at the anodic site and liberated electrons flow through the metal to cathodic sites where dissolved oxygen is available to consume them. For example, chloride ions react with iron compounds in the passive layer to create an iron chloride complex $\left(\mathrm{FeCl}_{2}\right)$, which subsequently reacts with hydroxide $\left(\mathrm{OH}^{-}\right)$from the surrounding concrete to form hydrated iron oxide compounds. This is commonly known as the anodic reaction. Simultaneously, at an alternate location on the steel surface, oxygen $\left(\mathrm{O}_{2}\right)$ reacts with water $\left(\mathrm{H}_{2} \mathrm{O}\right)$ and electrons released by the anodic reaction to form hydroxide. This is referred to as the cathodic reaction. Together, the anodic reaction and the cathodic reaction form a corrosion cell [10-19].

As discussed above, the process of corrosion of steel in concrete is generally considered as being electrochemical in nature, and the basic mechanisms of electrochemical theory of corrosion developed for liquid electrolytes apply for modeling here [20-21]. However, electrochemical corrosion modeling of iron in concrete has a number of characteristic differences that are determined by the peculiarities of electrochemical

*Corresponding author: Raja Rizwan Hussain, Assistant Professor in CoE-CRT, Civil Engineering Department, College of Engineering at King Saud University, Riyadh, Saudi Arabia, Tel: +966-590011078; Fax: +966-1-4696355; E mail: raja386@hotmail.com

Received January 25, 2014; Accepted January 27, 2014; Published February 03, 2014

Citation: Hussain RR (2014) Modeling of Corrosion; Steel, Concrete and Environment. J Civil Environ Eng 4: e114. doi:10.4172/2165-784X.1000e114

Copyright: (c) 2014 Hussain RR. This is an open-access article distributed under the terms of the Creative Commons Attribution License, which permits unrestricted use, distribution, and reproduction in any medium, provided the original author and source are credited. 
processes in the complex "concrete electrolyte", the properties of which are affected by the micro structure of the concrete and service exposure conditions. Concrete is a highly heterogeneous and complex structure, which contains a heterogeneous distribution of different types and amounts of solid phases, pores, and micro cracks (Mehta P.K, 1993). In addition, the structure of concrete is also subject to change with time, environmental humidity and temperature. A large amount of water can exist in the hydrated cement paste, depending on the environmental humidity, porosity and pore size distribution of the hydrated cement paste. The presence and transport of the corrosion reactants (water, oxygen and various ions), the corrosion products, and the passage of the ionic current necessary to support corrosion are normally confined to the cement paste phase-cement paste pore solution and the structure and distribution of pores.

The composition of the pore solution is the decisive factor in determining whether embedded steel will be passivated or whether it will actively corrode. Researchers on the influence of a number of factors on the composition of pore solution [21-23] have shown that the presence of sodium and potassium oxides in the cement, as well as calcium hydroxide produced in the hydration reactions of cement components can give the pore solution of ordinary portland cement a $\mathrm{pH}$ of about 13 while the $\mathrm{pH}$ of blended cement is somewhat lower. The range of high $\mathrm{pH}$ values of typical concrete is within the $\mathrm{pH}$ domain in which insoluble oxides of iron are thermodynamically stable to maintain a passive film on steel surface. Unfortunately, the $\mathrm{pH}$ value of concrete can be reduced by carbonation and by leaching.

Generally the best measure of corrosivity of concrete is its conductivity, usually expressed as the reciprocal, the resistivity. A low concrete resistivity indicates a high corrosive activity. The resistivity of the concrete is mainly determined by the salt content in the pore water, degree of saturation and temperature. The resistivity of the concrete can vary widely for different conditions [24-27]. Gjorv [25] has reported resistivity values of 7,000 and $6,000,000 \mathrm{~W} \mathrm{~cm}$ for $100 \%$ and $20 \%$ saturated concrete, respectively, which are possible in natural environments. High water/cement ratio, chloride bearing, saturated concrete provide the lower resistivity, while low water/cementratio, well cured, dry concrete provides the highest. There is an absence of complete correlation between electrical resistivity and concrete corrosivity.

In this editorial, corrosion modeling of steel in concrete is based on electrochemical processes. The corroding model system consists of an anode in which steel is corroded, a cathode, an electrical conductor, and an electrolyte (concrete pore solution). The potential difference between anode and cathode is the driving electrical force for steel corrosion. The modeling process is divided into primary electrochemical processes and secondary processes. Since the volume of rust products is much higher (about 4 to 6 times) than that of the iron, the formation of rust products will lead to cracking and spalling of the cover concrete when expansive stress exceeds the tensile strength of the concrete, and reduction of steel reinforcing cross section may lead to structure failure.

Reinforcement corrosion in concrete is essentially an electrochemical process, where at the anode iron is oxidized to iron ions that pass into solution, and at the cathode oxygen is reduced to hydroxyl ions. The anode and the cathode form a short circuited corrosion cell formed within the concrete, with the flow of electrons in the steel and of ions in the concrete pore solution [28]. Depending on various factors such as the $\mathrm{pH}$ value of the pore solution, the availability of oxygen and moisture, the content of aggressive agents etc., the corrosion products possess complex stochiometry and may expand by about four to six times the original volume of iron corroded. Two corrosion products are generally thought to be dominant - ferrous hydroxide $\mathrm{Fe}(\mathrm{OH})_{2}$ and hydrated red rust $\mathrm{Fe}(\mathrm{OH})_{3}$ [29-32]. Faraday's law forms the foundation for all existing reinforcement corrosion models that assume a constant rate of iron consumption and rust generation. To understand the mechanical effects of rust expansion, a corrosion-induced rust expansion model is illustrated [33].

Water-cement ratio in the original mix plays a decisive role in determining the pore structure of the hardened cement past. The excess water which cannot be consumed in the hydration process is the direct cause of the high degree of porosity in ordinary cement. This high degree of porosity causes to increase the penetration rate of the aggressive ions inside concrete and subsequently the depassivation. As the water-cement ratio increases oxygen permeability also increases. Also increase in the water-cement ratio increases the carbonation depth. Ohno et al., [34] reported that rust area increases as the watercement ratio increases. The narrower and more twisted the pores of the hardened cement pastes the more the transport is obstructed and this reduces the corrosion rate. Miyazato [35] reported that in case of $\mathrm{Cl}^{-}$induced corrosion, the decrease of the water-cement ratio made the macro cell corrosion activated. On the other hand, increasing the water-cement ratio made the microcell corrosion activated. The progress of steel corrosion in concrete is easily influenced by $\mathrm{pH}$ in pore solution surrounding steel. Evans [36] reported that the corrosion rate increased as the $\mathrm{pH}$ of concrete decreased in the condition of $\mathrm{pH}$ lower than 10. Montemor et al., reviewed the steel corrosion monitoring techniques including potential measurements, polarization resistance measurements, electrochemical impedance spectroscopy (EIS), and transient techniques. Half-cell potential measurement is one of the simplest methods to assess state of steel corrosion. ASTM C876 provides standard test method for half-cell potential measurement of uncoated rebar in concrete structure. Guideline for interpreting measured halfcell potential value is provided by ASTM C876. However, there are many factors should be considered before interpreting results such as condition of cover concrete, or type of rebar. Uomoto (2000) showed that measured half-cell potential values at concrete surface could be considered as actual value at steel surface, if cover depth was within $20 \mathrm{~mm}$. Gu and Beaudoin [37] reported that interpretation criteria of ASTM C876 is most applicable for corrosion due to chloride. Stern et al., showed that for a simple corroding system, the polarization curve for a few milli volts around the corrosion potential obeys a quasilinear relationship. The slope of this relationship is called "Polarization Resistance". The value of $B$ factor is determined from the particular electrochemical cell and generally ranges from 13 to $52 \mathrm{mV}$ depending on the system. For measuring it, a potentiostat is necessary. Based on the theories of polarization resistance to obtain evidence of corrosion activity, two devices which are currently used for measuring the corrosion rate (corrosion current density) both in laboratory and in the field are K. CC. lear's 3LP [38] and Gecor device [39].

AC impedance technique is the application to the working electrode maintained at its corrosion potential by potentiostat of a small amplitude (a few milli volts, DE peak to peak) sinusoidal voltage in an extensive frequency range [40-42]. The detail test procedures of preparing, cleaning, and evaluating corrosion test specimens are described in ASTM-G1.The corrosion model in this editorial was firstly adopted from the previous research [43]. In the model a general scheme of micro-cell corrosion is introduced based on thermodynamic electro-chemistry. Tafel Diagram [3] is a useful tool for simulating the corrosion phenomenon. From the electric potential and the formation of passive layers, electric current that involves chemical reaction can be calculated so that the conservation law of electric charge should be satisfied in a local area. It is well documented [44-49] that the presence 
of chloride ions in reinforced concrete can cause the steel to corrode if sufficient oxygen and moisture are present to sustain the reaction. The chloride-induced corrosion is the most prevalent and damaging cause of corrosion of steel in concrete. The mechanism of chloride induced corrosion of steel is not yet fully understood. It is generally believed [50-55] that the chloride ions become incorporated in the passive film, replacing some of the oxygen and increasing both its conductivity and its olubility. The threshold concentration of chloride ions to initiate corrosion is controversial, because it is dependent on so many factors including quality of concrete (W/C ratio, mixture proportions, type of cement), relative humidity and temperature of the concrete, the $\mathrm{pH}$ of the pore solution and sulfated content [56-59].

The concrete capillary-pore system filled with water and air acts as the corrosive electrolyte. Apart from the pore structure, porosity and pore size distribution of the concrete, water content in the concrete is dependent on the local amount and time of rainfall, and external relative humidity and temperature. Certain water content in concrete is an essential requirement for corrosion to take place. As a rule, the presence of oxygen is also necessary for cathodic reaction process. If a pore volume of the concrete is only partly filled with water, transfer of oxygen will be easy to the steel surface by means of diffusion in the gas phase. Whereas, when a pore volume of the concrete is completely filled with water, then oxygen can reach the steel surface only by diffusion through the pore water, and the diffusivity of oxygen in water is about four powers lower than that in air [60].

Kobayashi [61] has reported that when moisture content of concrete is lowered from $80 \%$ to $40 \%$; the value of oxygen diffusion coefficient becomes approximately 15 times higher. Temperature of concrete can vary widely, depending on the geographiclatitude and climatic conditions and also on the time of year and day. The temperature dependence of the kinetics of electrode processes and processes of diffusion that take place in the concrete can be a certain degree expressed by the Arrhenius equation [60]. The process of steel corrosion in concrete, the rate of which is usually determined by the kinetics of diffusion or by the kinetics of electrode process, will generally rise exponentially with a rise in temperature, in accordance with the Arrhenius equation. However, because of the complexity of the corrosion process in the concrete, there can be quite a significant deviation from this dependence $[26,62]$. For example, if a high temperature is associated with more rapid drying or lower oxygen solubility in the concrete moisture, the temperature dependence of corrosion in concrete will usually be quite different. Clear [59] suggested that the corrosion current density measured at given field temperature can be adjusted to another temperature using some formulation given in his publication. Usually, penetration of a particular substance such as chloride ions into concrete can be in two forms: capillary attraction and ionic diffusion, depending on the degree of saturation in the concrete $[63,64]$.

The prediction of corrosion in RC structures due to environmental actions is complex and needs extensive research in this area. The methodology adopted by Hussain et al., [10-16] is based on a 3D finite element model developed by the research group. It is a computational program for the evaluation of various durability aspects of concrete related to material as well as environmental modeling such as concrete hardening (hydration), microstructure formation and several associated phenomenon, from casting of concrete to a period of several months or years. As such this tool can be utilized to study the effect of ingredient materials, environmental conditions as well as the size and shape of structure on the durability of concrete. The term durability considered here takes into account both the green concrete stage problems as well as matured concrete exposed to environment. This tool can be used to analytically trace the evolution of microstructure, strength and temperature with time for any arbitrary initial and boundary conditions. Since the main simulation program is based upon finite-element methods, it could be applied to analyze real life concrete structures of any shape, size or configuration. Furthermore, dynamic coupling of several phenomenons ensures that the effect of changing environmental conditions is easily integrated into the overall simulation scheme.

Summarizing all above in the model, a general methodology of micro-cell corrosion model is introduced based on thermodynamic electro-chemistry $[43,12-16,18,19]$. The corrosion process is assumed to occur uniformly over the surface area of reinforcement in a reference finite element volume. Some issues still need to be taken into account such as formation of pits due to the localized attack of chlorides and corrosion due to the formation of macro-cell. The beauty of this model is that all the requisite parameters such as $\mathrm{pH}$, temperature, partial pressure of oxygen, chloride concentration etc. are all obtained automatically from the connected sub-routines in the model for the computation of corrosion.

\section{References}

1. ASTM G15-99b (1999) Standard terminology relating to corrosion and corrosion testing, Annual Book of ASTM Standards.

2. Jones DA (1995) Principles and Prevention of Corrosion, Prentice-Hall.

3. Tafel J (1906) Zeitschrift für Eleckrochemie 12: 112-122 (In german).

4. Broomfield JP (1997) Corrosion of Steel in Concrete. Chapter 6, Electrochemical repair techniques, E and FN SPON, London.

5. Broomfield JP, Rodriguez J, Ortega LM, Garcia AM (1993) Corrosion Rate Measurements in Concrete Bridges by Means of the Linear Polarization Technique Implemented in a Field Device. Paper presented at $\mathrm{Cl}$ Fall Convention, Minneapolis, Minnesota, USA.

6. Turgoose S, Cottis RA (1998) Electrochemical kinetics and thermodynamics.

7. Adolf Fick (1858) Fick's law of diffusion governing the diffusion of a gas across a fluid membrane.

8. Barneyback RS, Diamand S (1981) Expression and Analysis of Pore Fluids from Harden Cement Pastes and Mortars. Cement Concrete Research11: 279 285

9. Page CL, Treadaway KWJ (1982) Aspects of Electrochemistry of Steel in Concrete. Nature 297: 109-115.

10. Hussain RR, Ishida T (2010) Development of Numerical Model for FEM Computation of Oxygen Transport through Porous Media Coupled with Micro-Cell Corrosion Model of Steel in Concrete Structures. Computers and Structures Journal 88: 639-647.

11. Hussain RR, Ishida T (2010) Influence of Connectivity of Concrete Pores and Associated Diffusion of Oxygen on Corrosion of Steel under High Humidity. Construction and Building Materials Journal 24: 1014-1019.

12. Hussain RR, Ishida T, Wasim M (2011) Experimental Investigation of Time Dependent Non Linear 3D Relationship Between Critical Carbonation Depth and Corrosion of Steel in Carbonated Concrete, Journal of Corrosion Engineering, Science and Technology 46: 657-660.

13. Hussain RR, Ishida T (2011) Investigation of Volumetric Effect of Coarse Aggregate on Corroding Steel Reinforcement at the Interfacial Transition Zone of Concrete. KSCE Journal of Civil Engineering 15: 153-160.

14. Hussain RR, Ishida T (2011) Enhanced electro-chemical corrosion model fo reinforced concrete under severe coupled actions of chloride and temperature. Construction and Building Materials Journal 25: 1305-1315.

15. Hussain RR, Ishida T (2011) Computer-Aided Oxygen Transport Model of Mass and Energy Simulation for Corrosion of Reinforced Steel. Automation in Construction Journal 20: 559-570.

16. Hussain RR, Ishida T, Wasim M (2012) Oxygen Transport and Corrosion of Steel in Concrete Under Varying Concrete Cover, W/C and Moisture, $\mathrm{ACl}$ Materials Journal 109: 3-10. 
17. Hussain RR (2011) Effect of moisture variation on oxygen consumption rate of corroding steel in chloride contaminated concrete. Cement \& Concrete Composites 33: 154-161.

18. Hussain RR, Ishida T (2012) Multi-Variable Empirical Analysis of Coupled Oxygen and Moisture for Potential and Rate of Quantitative Corrosion in Concrete. Journal of Materials in Civil Engineering, ASCE (American Society of Civil Engineering) 24: 950-958.

19. Hussain RR (2013) Computer Based FEM Stabilization of Oxygen Transport Model for Material and Energy Simulation in Corroding Reinforced Concrete, International Journal of Computers and Concrete, ISI 12: 669-680.

20. Cabrera JG (1996) Deterioration of Concrete Due to Reinforcement Steel Corrosion. Cement Concrete Composites 18:47-59.

21. Page CL, Vennesland $\varnothing$ (1983) Pore Solution Composition and Chloride binding capacity of Silica-Fume Cement Pastes. Materiaux Construct 16: 19 25.

22. Hansson MC, Markussen JB, Frølund T (1985) The Effect of Chloride Cation Type on the Corrosion of Steel in Concrete by Chloride Salts. Cem Concr Res 15: 65-73.

23. Byfors K, Hansson CM., Tritthart J (1986) Pore Solution Expression as a Method to Determine the Influence of Mineral Additives on Chloride Binding. Cem Concr Res 16:760-770.

24. Monfore GE (1968) Electrical Resistivity of Concrete. JPCA Res Develop Lab 2: $35-48$

25. Gjorv OE, Vennesland O, El-Busaidy AHS (1977) Proc-Annu. Offshore Technol Conf 9: 581-588

26. Alonso C, Andrade C, González JA (1988) Relation Between Concrete Resistivity and Corrosion Rate of the Reinforcements in Carbonated Mortar Made with Several Cement Types. Cem Concr Res 18: 687-698.

27. López W, González JA (1993) Influence of the Degree of Pore Saturation on the Resistivity of Concrete and the Corrosion Rate of Steel Reinforcement. Cem Concr Res 23: 368-376.

28. Bertolini L, Elsener B, Pedeferri P, Polder R (2000) Corrosion of steel in Concrete. Wiley-vch Verlag $\mathrm{GmbH}$ and Co. KGaA.

29. Pantazopoulou SJ, Papoulia KD (2001) Modeling Cover-Cracking due to Reinforcement Corrosion in RC Structures, Journal of Engineering Mechanisms 27: 342-351.

30. Thoft CP (2000) Stochastic modeling of the crack initiation time for reinforced concrete structures, Proceedings of 2000 ASCE Structures Congress, Philadelphia, USA.

31. Thoft CP (2001a) Corrosion crack based assessment of the life-cycle reliability of concrete structures, Proceedings of ICOSSAR 01, Newport Beach, California, USA.

32. Thoft CP. (2001b) What happens with reinforced concrete structures when the reinforcement corrodes? Proceedings of the 2nd International Workshop on Life-Cycle Cost Analysis and Design of Civil Infrastructure Systems, Ube, Yamaguchi, Japan

33. Chen D (2006) Computational framework for durability assessment of reinforced concrete structures under coupled deterioration processes, Graduates school of Vanderbilt, University.

34. Ohno, Suzuki Y, Araparnatorn (1994) Macro-cell corrosion of steel in un-cracked concrete. International conference on corrosion and corrosion protection of steel in concrete: $224-235$.

35. Miyazato S (2001) Study on Macro-cell corrosion induced by chloride attack or carbonation at defect in reinforced concrete, $\mathrm{PhD}$ thesis, Tokyo Institute of Technology, Japan.

36. Evans UR (1930) The corrosion and oxidation, Journal of chemistry

37. Gu P, Beaudoin JJ (1998) Obtaining Effective Half-cell Potential Measurements in Reinforced Concrete Structures. Institute for research in construction.

38. Clear KC (1990) Test Procedures, Data Analysis, and General Information. K.C.C. Inc. 3-LP Package, Sterling, Virginia.

39. Geocisa, Geotecnia Y, Cimientos SA (1991) Instructions Manual for Gecor Corrosion-Rate-Meter, Geocisa, Madrid, Spain.

40. Hope BB, Ip AK, Manning D (1985) Corrosion and Electrical Impedance in Concrete. Cem Concr Res 15: 525-534.
41. John DG Coote AT, Treadaway KWJ, Dawson JL (1983) The Repair of Concrete, A Laboratory and Exposure Site Investigation, Corrosion of Reinforcement in Concrete Construction. Society of Chemical Industry, London.

42. Andrade C, Soler L, Nóvoa XR (1994) Advances in Electrochemical Impedance Measurements in Reinforced Concrete. Electrochemical Methods in Corrosion Research, Proceedings of 5th International Symposium, Sosimbra, Portugal.

43. Maekawa K, Ishida T (1999a) An integrated computational system of mass/ energy generation, transport and mechanics of materials and structures, Thesis (PhD), University of Tokyo.

44. Stratfull RF, Jurkovich WJ, Spellman DL (1975) Corrosion Testing of Bridge Decks. Transportation Research Board.

45. Browne RD (1980) Mechanism of Corrosion of Steel in Concrete in Relation to Design, Inspection, and Repair of Offshore and Coastal Structures, Performance of Concrete in Marine Environments, American Concrete Institute, Detroit 65: 169-204.

46. Kilareski WP (1980) Corrosion Induced Deterioration of Reinforced Concrete An Overview. Materials Performance.

47. Slater JE (1978) Corrosion of Reinforced Steel in Concrete: Magnitude of the Problem. NACE, Chicago, USA.

48. Page CL (1988) Basic Principles of Corrosion, Corrosion of Steel in Concrete. RILEM Report, New York, USA

49. Tuutti K (1977) Corrosion of Steel in Concrete. 6th European Congress on Metallic Corrosion, London, UK.

50. Foley RT (1970) Role of the Chloride Ion in Iron Corrosion. Corrosion 26:58.

51. Cook HK, McCoy WJ (1977) Influence of Chloride in Reinforced Concrete. American Society for Testing and Materials 629: 20-29.

52. Fraczek J (1987) A Review of Electrochemical Principles as Applied to Corrosion on Steel in a Concrete or Grout Environment. Corrosion, Concrete, and Chloride 102: 13-24.

53. Erlin B, Verbeck GJ (1978) ACI SP-49: 39-46.

54. Fontana MG, Greene ND (1967) Corrosion Engineering, McGraw-Hill.

55. Sageo-Crentsil KK, Glasser FP (1990) Analysis of the Steel: Concrete Interface. Corrosion of Reinforcement in Concrete, Society of Chemical Industry, London.

56. SchiessI P, Raupach M (1990) Influence of Concrete Composition and Microclimate on the Critical Chloride Content in Concrete. Corrosion of Reinforcement in Concrete. Transportation Research Board: 49-58.

57. Hansson CM, Sørensen B (1990) Threshold Concentration of Chloride in Concrete for the Initiation of Reinforcement Corrosion. American Society for Testing and Materials, Philadelphia, 1065: 3-16.

58. Berman HA (1975) Sodium Chloride, Corrosion of Reinforcing Steel, and the $\mathrm{pH}$ of Calcium Hydroxides Solution. ACI Journal.

59. Clear KC (1983) Chloride at the Threshold. Report of Kenneth C. Clear Inc.

60. Tomoshov ND (1966) Theory of Corrosion and Protection of Metals, Mcmillan Co, New York, USA.

61. Kobayashi K, Shuttoh K (1991) Oxygen Diffusion of Various Cementitious Materials. Cem Concr Res 21: 273-284.

62. Thompson NG, Islam M, Lankard DA, Virmani YP (1995) Environmental Factors in the Deterioration of Reinforced Concrete. Materials Performance 34: 43-47.

63. Collepordi M., Marcialis A, Tuniziani R (1972) Penetration of Chloride lons into Cement Pastes and Concretes. Journal of the American Ceramic Society 55: 534-535.

64. Page CL, Short MR, Tarras El A (1981) Diffusion of Chloride lons in Hardened Cement Paste. Cem Concr Res 11: 395-406. 